\title{
Picea glauca dynamics and spatial pattern of seedlings regeneration along a chronosequence in the mixedwood section of the boreal forest
}

\author{
Tala AwADA ${ }^{\mathrm{a} *}$, Geoffrey M. HENEBRY ${ }^{\mathrm{b}}$, Robert E. REDMANN ${ }^{\mathrm{c}}$, Hari SulistiYOWATI ${ }^{\mathrm{c}}$ \\ ${ }^{a}$ School of Natural Resources, University of Nebraska-Lincoln, 12 D Plant Industry, Lincoln, NE 68583-0814, USA \\ $\mathrm{b}$ Center for Advanced Land Management Information Technologies (CALMIT), School of Natural Resources, \\ University of Nebraska-Lincoln, 113 Nebraska Hall, Lincoln, NE 68588-0517, USA \\ ${ }^{c}$ Department of Plant Sciences, University of Saskatchewan, Saskatoon, SK S7N 5A8, Canada
}

(Received 9 May 2003; accepted 6 February 2004)

\begin{abstract}
We studied Picea glauca dynamics in the boreal forest of Saskatchewan, Canada, using 35 stands ranging from $<1$ to $>200$ y after fire. We determined the spatial pattern and the importance of seedbed conditions to the recruitment of $P$. glauca. Basal area increased along the chronosequence peaking at $110 \mathrm{y}$ after fire $\left(51.5 \mathrm{~m}^{2} \mathrm{ha}^{-1}\right)$. The ratio of softwood to hardwood increased from 0.03 (16 y) to 17.0 (172 y). Picea glauca tree density increased with stand age, highest densities were observed in a $172 \mathrm{y}$ stand $\left(1413\right.$ stems ha $\left.^{-1}\right)$. Picea glauca dominated the canopy between 93 and 172 y after fire. Picea glauca snags appeared about 66 y after fire, and remained relatively low in density until $160 \mathrm{y}$. Saplings were present at varying densities along the chronosequence. Seedlings established immediately after fire and exhibited bimodality with lowest densities observed between 110 and $125 \mathrm{y}$. Analysis with Ripley's K, showed that seedlings were mainly distributed at random in young stands but were clumped at a distances $<12 \mathrm{~m}$ in old stands. In young stands, the majority of seedlings regenerated on the organic layer (LFH $73 \%$ ), while recruitment was almost exclusively on logs in old stands (94\%). Picea glauca regeneration depended on propagule availability and seedbed characteristics at early stand age. Logs and the resultant canopy gaps formed, appear to be critical for $P$. glauca regeneration in mature and old stands.
\end{abstract}

Picea glauca / boreal forest / stand dynamics / spatial pattern / Ripley's K

Résumé - Dynamique de Picea glauca et répartition spatiale de la régénération selon une chronoséquence située dans une zone de forêt mélangée de la forêt boréale. Nous avons étudié la dynamique de Picea glauca en forêt boréale du Saskatchewan au Canada, en utilisant 35 peuplements dont l'âge va de 1 à 200 ans après incendie. Nous avons étudié la répartition spatiale des semis et mis en évidence l'importance des conditions du milieu de germination pour la régénération de Picea glauca. La surface terrière augmente au cours de la chronoséquence, avec un pic à 110 ans après incendie $\left(51,5 \mathrm{~m}^{3}\right.$ par ha). Le rapport bois résineux sur bois feuillu s'accroît de 0,03 (16 ans) à 17,0 (172 ans) exprimé en surface terrière. La densité de tiges de Picea glauca augmente avec l'âge du peuplement, la plus forte étant observée dans un peuplement de 172 ans (1413 tiges/ha). Picea glauca occupe une place dominante dans le couvert entre 93 et 172 ans après incendie. On voit apparaître des Picea glauca morts sur pied, environ 66 ans après incendie ; ceux-ci restent peu nombreux jusqu'à 160 ans. On constate la présence de jeunes individus, en nombre plus ou moins grand, tout au long de la chronoséquence. Les semis s'installent aussitôt après incendie. Ils sont particulièrement denses à 50 et à 172 ans, avec un minimum entre 110 et 125 ans. L'analyse, à l'aide de la fonction de Ripley's K, montre que, dans les jeunes peuplements, les semis sont répartis au hasard, alors que dans les peuplements âgés, ils sont groupés par bouquets distants de moins de $12 \mathrm{~m}$. Dans les jeunes peuplements, la majorité des semis se développement sur la couche de matière organique du sol (73\%) alors que dans les vieux peuplements ils ne se développement presque exclusivement que sur les arbres tombés au sol, en voie de décomposition (94\%). La régénération de Picea glauca dépend de la disponibilité en semence viable et des conditions du lieu de germination, dans les jeunes peuplements. Pour les vieux peuplements, ce sont les bois au sol et les trous qui en résultent dans le couvert qui dont déterminants.

Picea glauca / forêt boréale / dynamique des peuplements / répartition spatiale / Ripley's K

\section{INTRODUCTION}

White spruce (Picea glauca (Moench) Voss) is one of the most widely distributed conifers in North American boreal forest. White spruce extends from Alaska, where it is the dominant species in the Brooks Range at the northern treeline [14] to Newfoundland in the east and from the treeline south to Montana and the New England States [1]. Fire is the major natural ecological factor controlling structure, function and composition in the western boreal forest of Canada [17]. The change in

\footnotetext{
*Corresponding author: tawada2@unl.edu
} 
structure of boreal forest along a chronosequence after disturbance has been described by Bergeron and Dansereau [6], Jarvis et al. [23], Rowe [34], Thorpe [36] and Viereck [39], among others. The speed of tree regeneration following disturbances depends on many factors including seed availability, disturbance type, and seedbed characteristics [17]. In general, on mesic sites in the mixedwood section of the boreal forest, the shade intolerant, fast-growing trembling aspen (Populus tremuloides (Michx.)) and other deciduous hardwoods regenerate readily following disturbance and quickly dominate the canopy [5]. On sites where the organic layer has been removed, white spruce (Picea glauca (Moench) Voss) seedlings may establish if seeds are available [24]. Any established white spruce seedlings are usually overtopped by aspen and remain for decades in subordinate position until canopy gaps are formed [28]. During the this period (around $80 \mathrm{y}$, [24]), trembling aspen dies back and white spruce is released from the understory, assuming dominance in the stand. Elliot-Fisk [11] lists some of the environmental changes that take place along the chronosequence in the boreal forest in response to canopy closure. These include an increase in thickness of the organic layer or the LFH (Litter, Fermented and Humus layers), and decreases in available nutrients, soil temperature, and soil drainage, resulting in anaerobic conditions and an increase in frost heave and thrust.

The mixedwoods are the most productive and managed sections in the boreal forest ecosystems [8]. In the last two decades, there has been a rapid move to using ecosystem based approaches that mimic natural stand dynamics in forest management and restoration in the boreal forest [19]. To mimic natural stand dynamics, it is essential to understand the ecology and dynamics of boreal species. While there is a rich body of literature on the survival and seedbed characteristics of boreal species like black spruce (Picea mariana) and jack pine (Pinus banksiana) [18], there has been little comparable work done on the recruitment, spatial distribution and seedbed preferences of $P$. glauca [7], the most widely distributed and economically important conifer in North American boreal forest. In this paper, our objectives are to describe the population dynamics of white spruce through extensive sampling of trees, saplings, seedlings, and snags following fire in the mixedwood section of the boreal forest. Further, we quantitatively characterize the spatial pattern of seedlings and the importance of seedbed conditions to the success of recruitment and survival of white spruce along a 200 year chronosequence.

\section{METHODS}

\subsection{Study area}

The study area was located in the mixedwood section of the southern boreal forest of Saskatchewan, Canada. The area falls between $53^{\circ}$ $38^{\prime}$ and $54^{\circ} 41^{\prime} \mathrm{N}$ latitude, and $105^{\circ} 00^{\prime}$ and $106^{\circ} 20^{\prime} \mathrm{W}$ longitude. The climate is cool continental, characterized by long cold winters and short warm summers. Monthly average temperatures vary from $-20{ }^{\circ} \mathrm{C}$ in January to $17^{\circ} \mathrm{C}$ in July and the annual average precipitation is around $450 \mathrm{~mm}$ [4] with approximately $70 \%$ falling as rain from June through August [20]. Soils are mainly orthic gray luvisols and brunisolic gray luvisols; a more detailed description of soil characteristics is provided by Thrasher-Haug [37]. The vegetation on mesic sites is dominated by white spruce (Picea glauca (Moench) Voss), bal- sam fir (Abies balsamea (L) Mill), trembling aspen (Populus tremuloides Michx), balsam poplar (Populus balsamifera L.) and paper birch (Betula papyrifera Marsh.). Important understory species are bunchberry (Cornus Canadensis L.), twin flower (Linnea borealis L.), sarsaparilla (Aralia nudicaulis L.), bishop's cap (Mitella nuda L.) and dewberry (Rubus pubescens Raf.) [4, 37]

With the use of forest inventory and topographic maps, 35 stands were selected in and around the Prince Albert Model Forest (PAMF), a member of the Canada Model Forest Network. PAMF encompasses 315000 ha in the mixedwood section of the boreal forest. PAMF includes land situated within a National park, a reserve land, and a Crown land. The selected stands spanned a chronosequence ranging from less than one year to $201 \mathrm{y}$ after fire. Stand selection was based on topography, soil characteristics, time since fire, and species composition. Time since fire was estimated by measuring ages of the largest overstory white spruce and aspen and/or taken directly from forestry records (for more details see Thrasher-Haug [37]).

\subsection{Picea glauca population dynamics}

In each stand, a $40 \mathrm{~m} \times 20 \mathrm{~m}$ plot was established and further divided into 32 quadrats of $5 \mathrm{~m} \times 5 \mathrm{~m}$. Tree density (height $>4 \mathrm{~m}$ ) and diameter at breast height $(\mathrm{dbh}, \mathrm{cm})$ of the dominant tree species (Picea glauca, Populus tremuloides and Abies balsamea) were recorded, and basal area was calculated. White spruce ( $P$. glauca) tree height was measured with an Abney hand level [22]. Picea glauca sapling (height $0.5-4 \mathrm{~m}$ ), seedling (height $<0.5 \mathrm{~m}$ ), and snag (standing dead; height $>4 \mathrm{~m}$ ) densities were also recorded.

\subsection{Spatial analysis and seedbed characteristics}

Using the quantitative results from the 35 stands, regression analysis were performed and nine representative plots of the average species composition for a specific stand age were chosen for the detailed sampling of $P$. glauca seedling pattern: younger $(5,16,43$ y) (the 43 y old plot did not have any seedlings and therefore was not included in the spatial analysis), mature (76, 77, $93 \mathrm{y})$ and older $(157,172,201 \mathrm{y})$ stands. The locations of all seedlings were mapped, and substrate characteristics next to each seedling were recorded; specifically, whether the seedling was found on the LFH (Litter, Fermented, Humus layers), on decomposing logs, or on mineral soil. At each plot, the LFH thickness was measured at the center of each $5 \times 5 \mathrm{~m}$ quadrat ( 32 readings per plot).

Ripley's K function second-order analysis was used to characterize the spatial patterns of the mapped seedlings. Ripley's K function [32, 38 ] tallies the number of occurrences within a given distance $(t)$ across a range of distances available within the sampling area. For a spatially random Poisson process, $K(t)=\pi t^{2} . K$ can be estimated $(\hat{K})$ by this function that includes edge correction [9]:

$$
\hat{K}(t)=a / n^{2} \sum_{i}^{n} \sum_{j}^{n} w_{i j} I_{t}(i, j)
$$

where $a$ is the area of the sample plot; $w_{i j}$ is a weighing factor used for edge effect correction $\left(w_{i j}=1\right.$ when the circle centered on $i$ with a radius $t$ lies totally within $a$, otherwise it is inversely proportional to the circle circumference that lies within the plot); $I_{t}(i, j)$ is a counter and is equal to 1 when the distance between $i$ and $j$ is less than $t$ and 0 otherwise; and $n$ is the number of occurrences in $a$. A variance-stabilizing transform of $\hat{K}$ makes it easier to evaluate deviations from Poisson randomness:

$$
L(t)=\sqrt{\hat{K}(t) / \pi} .
$$

Plotting $L(t)$ against distance $t$ produces a straight line with a slope 1 when the point distribution is random. Deviations from such a line can be described as clumped, random or even, for any distance $t$ up to approximately half the length of the shortest plot side $[9,30]$. Significance 


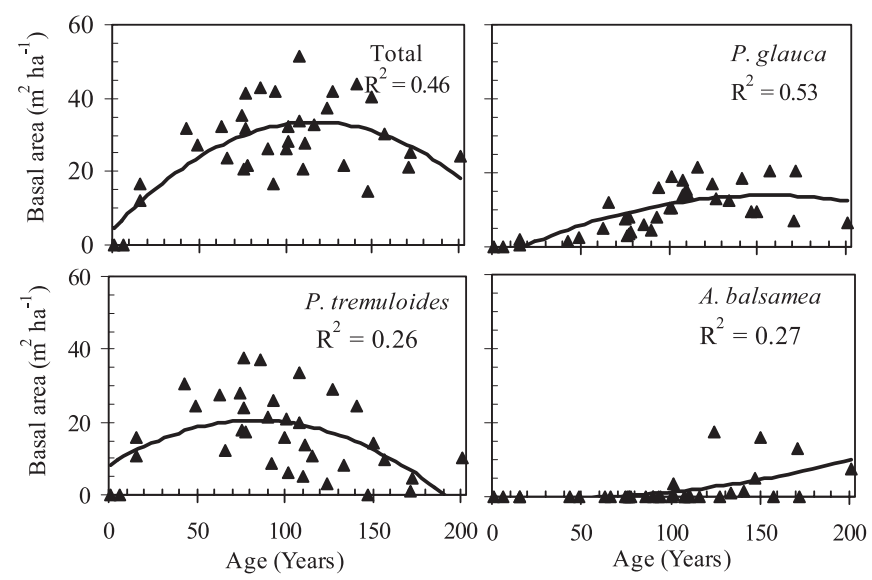

Figure 1. Total basal area $\left(\mathrm{m}^{2} \mathrm{ha}^{-1}\right)$, and basal area distribution of Picea glauca, Populus tremuloides and Abies balsamea along a chronosequence after fire (35 stands), in the mixedwood section of Saskatchewan boreal forest.

of $L(t)$ is determined using simulations of the randomized data sets [38] Using S-Plus, empirical confidence interval envelopes were established as the maximum and minimum values of $L(t)$ from $10^{3}$ simulations. $L(t)$ values exceeding the envelopes are considered non-random: slopes larger than the confidence interval indicate clumped distribution and slopes smaller than the confidence interval indicate a more even distribution.

\section{RESULTS}

\subsection{Basal area}

Basal area along the chronosequence increased in the first $50 \mathrm{y}$ after fire, and showed little directional change between 50 and $165 \mathrm{y}$, peaking at $110 \mathrm{y}$ after fire $\left(51.5 \mathrm{~m}^{2} \mathrm{ha}^{-1}\right)$, before started to decline in old stands $\left(24.4 \mathrm{~m}^{2} \mathrm{ha}^{-1}\right.$ in a $201 \mathrm{y}$ stand) (Fig. 1). During the period between 50 and $165 \mathrm{y}$, stands shifted from being deciduous to coniferous dominated. The ratio of softwood to hardwood basal area increased from 0.03 in a $16 \mathrm{y}$ stand to 17.0 in a 172 y stand. Populus tremuloides constituted $96 \%$ of the total basal area in a 16 y stand and remained the dominant tree species until 93 y. Picea glauca dominated the tree canopy between 93 and 172 y coinciding with increasing $P$. tremuloides mortality. Abies balsamea trees were mainly found in older (>125 y) stands (Fig. 1).

\subsection{Picea glauca dynamics}

Picea glauca tree density and height increased gradually along the chronosequence after fire (Figs. 2 and 3). Trees ( $>4 \mathrm{~m}$ ) were first observed in two 16 y plots after fire $\left(444\right.$ stems ha $\left.^{-1}\right)$. Maximum density of $P$. glauca (1413 stems ha ${ }^{-1}$ ) was in a stand aged $172 \mathrm{y}$, although the oldest stands averaged about 600 stems ha $^{-1}$. The average tree height increased with age after fire to peak between 110 and 127 y (Fig. 3). The largest trees averaged $26 \mathrm{~m}$ tall with a dbh of $69 \mathrm{~cm}$. During the period of white spruce dominance (93 to $172 \mathrm{y}$ ), the average tree height was $20 \mathrm{~m}$ and dbh was $17 \mathrm{~cm}$.

Picea glauca snag density along the chronosequence was made up of two cohorts: residual snags originating from the preburn stands and new snags originating within the current stand (Fig. 2). Residual snags density averaged 419 stems ha ${ }^{-1}$ immediately after fire, and declined as they fell to the ground by 5 to $16 \mathrm{y}$ after fire. The new $P$. glauca cohort of snags appeared at about $66 \mathrm{y}$ after fire, but remained relatively low until 160 y after fire.

Saplings $(0.5-4 \mathrm{~m})$, even though were present at varying densities (Fig. 2) seemed to gradually increase along the chronosequence with high densities observed at 16, 135 and $172 \mathrm{y}$ after fire $\left(2300,1400\right.$ and 1200 stems ha $^{-1}$, respectively). Seedlings ( $<0.5 \mathrm{~m}$ height $)$ established immediately after fire during the initial phase of succession, behaving as a pioneer species (Fig. 2). Recruitment continued at varying densities, peaking $50 \mathrm{y}$ after fire $\left(1250 \mathrm{stems} \mathrm{ha}^{-1}\right)$. During the following decades,
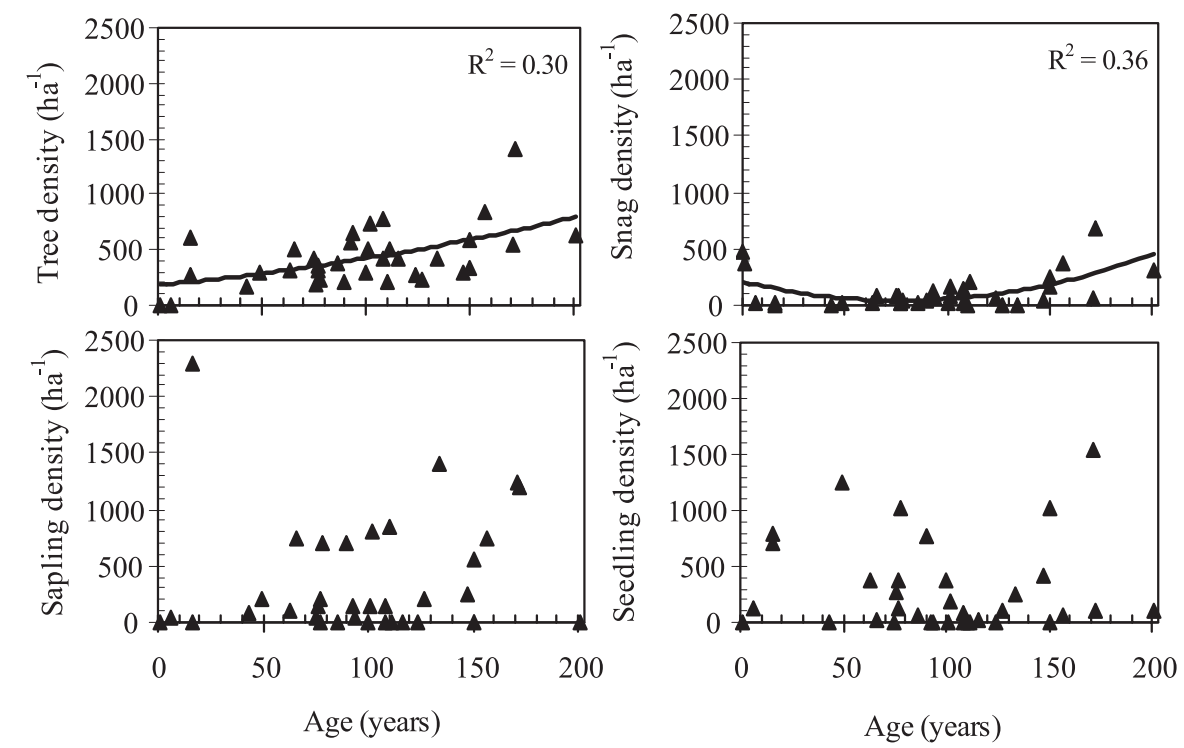

Figure 2. Picea glauca tree, snag, sapling and seedling densities $\left(\mathrm{ha}^{-1}\right)$ along a chronosequence after fire ( 35 stands), in the mixedwood section of Saskatchewan boreal forest. 


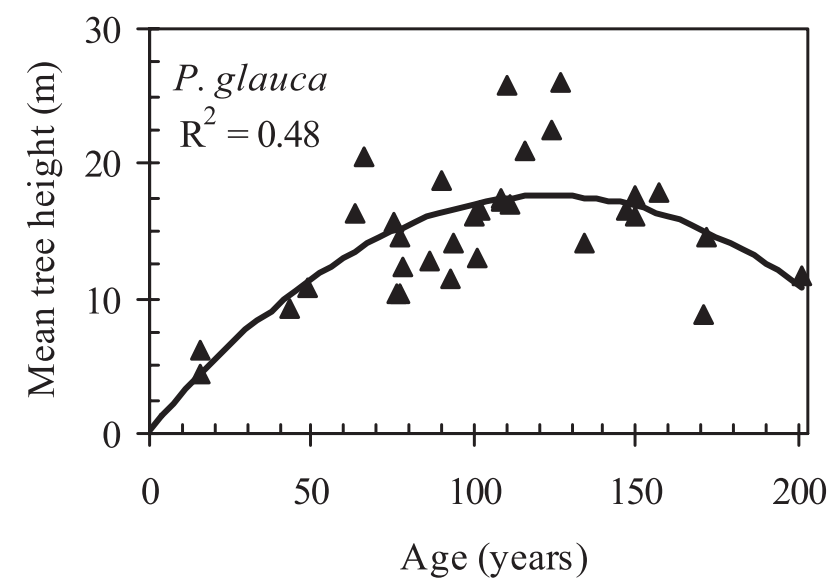

Figure 3. Mean tree height (m) of Picea glauca along a chronosequence after fire (35 stands), in the mixedwood section of Saskatchewan boreal forest.

recruitment decreased to reach its lowest levels between 110 and $125 \mathrm{y}$. A second wave of recruitment started at $127 \mathrm{y}$ and peaked at 172 y $\left(1537\right.$ stems ha $\left.^{-1}\right)$. Large variability in saplings and seedlings densities was reported, this was attributed to variability in site conditions such as the presence of mature producing trees, soil moisture, organic layer thickness, dead woody debris, microclimate and predation.

\subsection{Spatial pattern of seedlings and seedbed characteristics}

Picea glauca seedlings were present in all stands selected for intensive study, except for a 43 y stand. Recruitment pattern of $P$. glauca seedlings changed along the chronosequence. $L(t)$ analysis (Fig. 4) showed that the spatial distribution of $P$. glauca seedlings was mainly random in 5, 16, 76, 77 y stands. In a $16 \mathrm{y}$ stand, seedlings were clumped at distances of $2.5-3 \mathrm{~m}$. Spatial distribution was significantly clumped at scales of 1-8 $\mathrm{m}, 1-12 \mathrm{~m}, 1-6 \mathrm{~m}$ and $1 \mathrm{~m}$ in mature $93 \mathrm{y}$, and old 157,172 and 201 y stands, respectively. In addition, seedlings were evenly distributed at $15-20 \mathrm{~m}$ in 93 y stand.

Over all sites, around $60 \%$ of $P$. glauca seedlings were established on logs and $40 \%$ on the forest floor (LFH) (Tab. I). Seedlings in the younger age class ( 0 to $43 \mathrm{y}$ ) occurred mainly on LFH (73\%) rather than on logs (27\%). In older plots (> $157 \mathrm{y}$ ), the recruitment occurred almost exclusively on $\operatorname{logs}(94 \%)$. In mature stands (76 to $93 \mathrm{y}$ ), $45 \%$ of seedlings recruitment was found on $\operatorname{logs}$ and $55 \%$ on LFH. The thickness of LFH increased along the chronosequence from an average of $6.4 \mathrm{~cm}$ in the $5 \mathrm{y}$ stand to $13 \mathrm{~cm}$ in the $172 \mathrm{y}$ stand (Fig. 5A). This increase in LFH was accompanied by a significant decline in seedling recruitment on this layer (Fig. 5B).

\section{DISCUSSION}

Total basal area increased in the first few decades and, despite the little directional change between $50 \mathrm{y}$ and $165 \mathrm{y}$, stands shifted from being dominated by $P$. tremuloides to being dominated by $P$. glauca. This shift resulted in part from the mortality of P. tremuloides. Kazbems et al. [24] suggested that around $80 \mathrm{y}, P$. tremuloides started to senesce in Saskatchewan
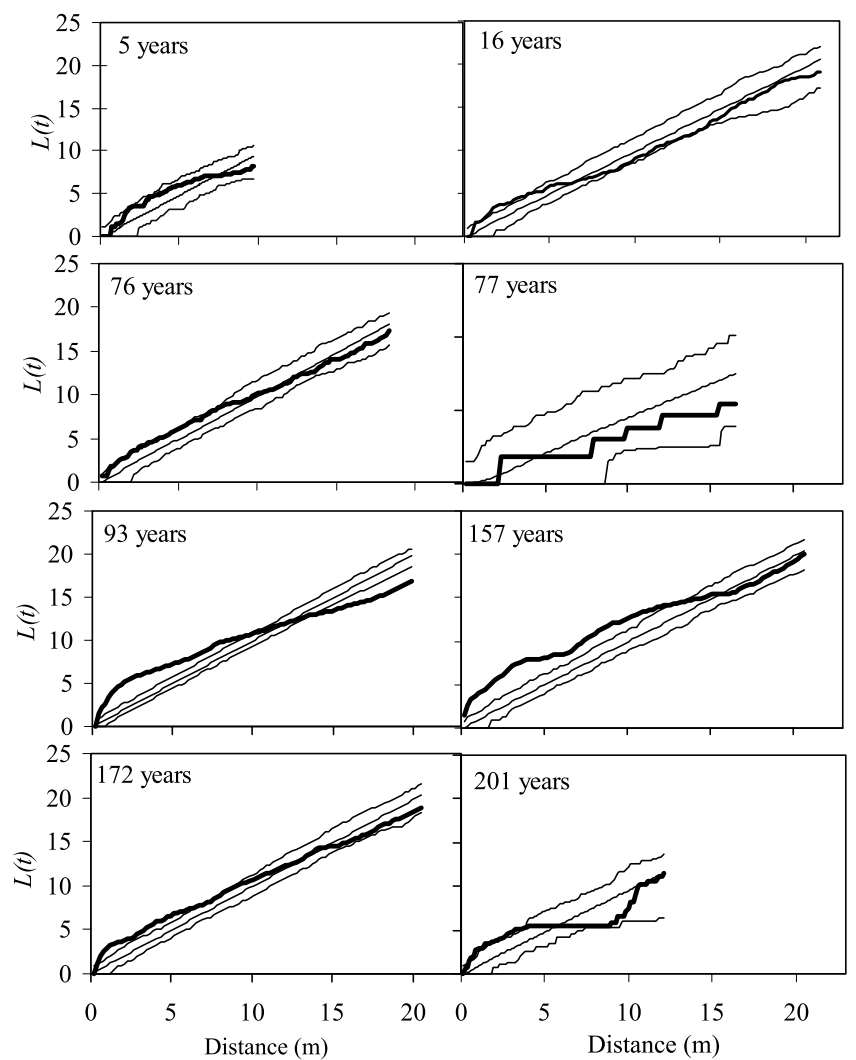

Figure 4. $L(t)$ values of spatial distribution of Picea glauca seedlings in $5,16,76,77,93,157,172$ and $201 \mathrm{y}$ stands in the mixedwood section of Saskatchewan boreal forest. The solid line shows the $L(t)$ values, while the dotted line shows the confidence envelope and the average of 1000 simulations. When the solid line is above (or below) the confidence envelope, the spatial pattern at that distance is significantly more clumped (or more even) than random expectation.

Table I. Picea glauca seedling density $\left(\mathrm{ha}^{-1}\right)$, substrate preference and $\log$ volume $(\mathrm{dbh}>10 \mathrm{~cm})$ in nine stands along the chronosequence after fire in the mixedwood section of Saskatchewan boreal forest.

\begin{tabular}{lcccc}
\hline Stand age & $\begin{array}{c}\text { Seedling density } \\
\left(\mathrm{ha}^{-1}\right)\end{array}$ & $\begin{array}{c}\text { Substrate preference } \\
(\% \text { seedlings })\end{array}$ & $\begin{array}{c}\text { Log volume } \\
\left(\mathrm{m}^{3} \mathrm{ha}^{-1}\right)\end{array}$ \\
\cline { 3 - 4 } & & Logs & LFH & \\
\hline 5 & 162 & 23 & 77 & 165 \\
16 & 375 & 30 & 70 & 208 \\
43 & 0 & 0 & 0 & 36.7 \\
76 & 325 & 38.5 & 61.5 & 156 \\
77 & 75 & 32 & 68 & 20.8 \\
93 & 737 & 63 & 37 & 72.8 \\
157 & 150 & 83 & 17 & 93.6 \\
172 & 612 & 100 & 0 & 53.2 \\
201 & 137 & 100 & 0 & 50.2 \\
\hline
\end{tabular}

boreal forest, releasing $P$. glauca from the understory. At a stand age $175 \mathrm{y}, P$. glauca density declined, releasing $A$. balsamea from competition and forming an uneven aged stand (201 y), dominated by A. balsamea, $P$. glauca and some scattered P. tremuloides. 

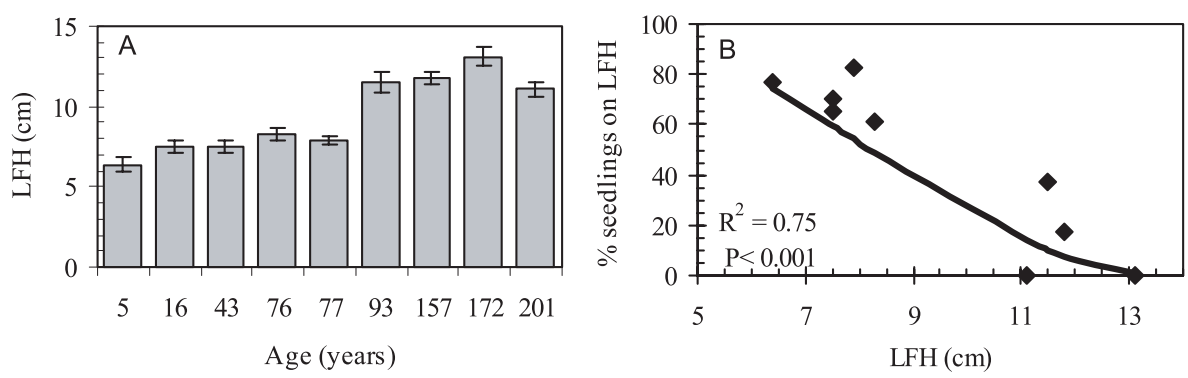

Figure 5. (A) Mean forest floor thickness (LFH, cm) \pm two standard errors; (B) Percentage of seedling recruitment on the LFH as a function of LFH thickness. Line shows back-transformed prediction from simple linear regression on arcsine transformed percentage data.

Picea glauca tree density increased gradually along the chronosequence. These trees were generally overtopped at least $2 \mathrm{~m}$ by $P$. tremuloides. The height difference further increased (by around $7 \mathrm{~m}$ ) until $77 \mathrm{y}$ after fire before $P$. glauca began to catch up [35]. Similar findings were reported for Manitoba's mixedwood boreal forest [10] and the southern Canadian boreal forest of Quebec [6]. As stands aged, and in the absence of major disturbances, $P$. glauca tree density commenced to decline and snag density to increase as it became incapable of successfully reproducing [29].

Saplings were present in 25 of the 35 sampled plots. Highest sapling densities were observed $16 \mathrm{y}$ after fire, indicating the potential importance of $P$. glauca on sites where high initial regeneration occurs immediately after fire in shaping the composition and structure of the forest. There was a large variation in both sapling densities along the chronosequence, and saplings heights and ages within stands reflecting more or less continuous regeneration. Ages varied between 5 and $34 \mathrm{y}$ and heights between 1 and $4 \mathrm{~m}$ in some sampled stands [2]. Seedling density exhibited bimodality with peaks at both $50 \mathrm{y}$ and $172 \mathrm{y}$. Regeneration was lowest between 110 and 125 y after fire. Galipeau et al. [13] found that white spruce recruitment after fire was characterized by two peaks: one shortly after fire (5-20 y) and a second smaller peak at around $50 \mathrm{y}$. The large variability in seedling density suggests that white spruce recruitment after fire was site specific and seemed to be associated with available seedbed and seed trees, since the white spruce seed bank is severely depleted by fire [27]. In older stands, the decline of white spruce establishment (110-125 y) was in part associated with canopy closure by coniferous species. Light intensities were reduced to around $10 \%$ between $110-125$ y, which limits white spruce growth [3]. In contrast, $35 \%$ of full sunlight was transmitted in a 38 y stand dominated with $P$. tremuloides, yielding sufficient insolation to support $P$. glauca establishment and growth [2]. The second peak in seedlings recruitment (172 y) may have resulted from higher density of seed trees, increased light intensity due to gap formation, and increased availability of microsites especially logs. Some older stands (150, 170 and 201 y) showed few white spruce and these stands were dominated by a thick organic and moss layers and a medium to dense cover of balsam fir seedlings and saplings [37]. The continuous advanced regeneration reported in this study has been mostly overlooked in forest management, but has the potential of replacing the overstory following natural disturbances or harvesting.
Population distributions can occur in spatial arrangements that range from uniform to random to clumped. Observed spatial patterns can reflect the reproduction properties of a species, microsite variability, interaction of species with its environment and other organisms, in addition to the spatial and temporal characteristics of the observing process [21,40]. Analysis with Ripley's K showed that the pattern of seedlings recruitment changed along the chronosequence. Picea glauca seedlings were mainly distributed at random in the younger and the mature stands but they were clumped at distances $<12 \mathrm{~m}$ in older stands. No seedlings were found on mineral soils (despite mineral soil exposure immediately after fire). Charron and Greene [7] reported that mineral soils were a more favorable seedbed for white spruce in a sowing experiment than litter or organic layer. In our study, the majority of seedlings regenerated at random on LFH in younger stands. Seedlings in older plots, were found almost exclusively on decaying logs (logs that were either partially degraded with bark partially or entirely sloughed, or logs starting to be integrated into the soils). In some cases, several individuals were established on the same log leading to a tightly clumped linear pattern. This clumpy pattern in older stands indicates that logs provided a more suitable microsite for $P$. glauca recruitment than LFH. Gray and Spies [16] reported that substrate characteristics were more important for the establishment of Tsuga heterophylla than gap size in Oregon. In closed canopied forests, establishment of $T$. heterophylla on logs was significantly greater than establishment on the litter layer, due to the higher moisture content of wood compared to litter in summer [16] and the burial of seedlings by litter during snow melt in the spring [15]. Our results have shown that regeneration on logs increased from $63 \%$ of total seedlings in $93 \mathrm{y}$ stand to $100 \%$ in 172 and $201 \mathrm{y}$ stands. The important role of logs for seedling establishment is well known in several forest types [25, 27, 33]. Logs provide moisture during the summer; reduce the barrier to seedling establishment posed by the mosses and litter; and provide an elevated environment for better light competition. In contrast, the thick layer of undecomposed litter, the lower soil temperatures, and light intensities in older stands limit $P$. glauca regeneration. Seedlings established on LFH of less than $8 \mathrm{~cm}$, but LFH greater than $12 \mathrm{~cm}$ seemed to significantly impair $P$. glauca recruitment [12]. Knapp and Smith [26] reported that Picea englemanii were mostly located in areas with thin $(2 \mathrm{~cm})$ LFH. Place [31] found that $5 \mathrm{~cm}$ of undecomposed litter (L layer) inhibited the establishment of $P$. glauca while $7 \mathrm{~cm}$ was needed to inhibit the establishment of A. balsamea. 
Our results show that Picea glauca regeneration depends on the presence of propagules and seedbed characteristics at early stand age and, in older stands, on the presence of suitable microsites. Initial recruitment of $P$. glauca was also shown to be essential for the success of this species, especially for providing the basal area and the recruitment of the second wave of seedlings or advanced regeneration associated with the opening of the canopy. Logs created by the death of $P$. tremuloides and the resultant canopy gaps formed, appear to be critical for $P$. glauca regeneration in mature and old stands. Natural regeneration may be enhanced by taking advantage of the advanced regeneration during harvesting operations.

Acknowledgments: This work was supported by the Prince Albert Model Forest Association and the University of Saskatchewan, Canada. We would like to thank the staff of the Prince Albert National Park for providing information on locations, origin and management history for stands in the Prince Albert Model Forest region. We thank Jocelyn Thrasher-Haug for her help with the fieldwork and Dr D. Wedin for his comments on an earlier version of the manuscript. T.A. Awada acknowledges support from the McEntire Stennis Funds, USDA. G.M. Henebry acknowledges support from NSF 0196445. We also thank the reviewers for their constructive comments that greatly improved the manuscript.

\section{REFERENCES}

[1] Attree S.M., Dunstan D.I., Fowke L.C., White spruce (Picea glauca (Moench) Voss) and black spruce (Picea mariana (Mill) B.S.P.), Biotech. Agric. For. 16 (1991) 423-445.

[2] Awada T., Spatial, Functional and Genetic Characteristics of Fieldplanted and Naturally-regenerated Populations of White Spruce (Picea glauca (Moench) Voss), Ph.D. thesis, University of Saskatchewan, Saskatoon, Saskatchewan, 2000.

[3] Awada T., Redmann R.E., Acclimation to light in planted and naturally-regenerated populations of white spruce seedlings, Can. J. Bot. 78 (2000) 1495-1504.

[4] Beckingham J.D., Nielsen D.G., Futoransky V.A., Field guide to ecosites of the mid-boreal ecoregions of Saskatchewan, UBC Press, Vancouver, 1996.

[5] Bergeron Y., Charron D., Postfire stand dynamics in a southern boreal forest (Quebec): a dendrological approach, Écoscience 1 (1994) 173-183.

[6] Bergeron Y., Dansereau P.R., Predicting the composition of the southern boreal forest in different fire cycles, J. Veg. Sci. 4 (1993) 827-832.

[7] Charron I., Greene D.F., Post-wildfire seedbeds and tree establishment in the southern mixedwood boreal forest, Can. J. For. Res. 32 (2002) 1607-1615.

[8] Chen H.Y.H., Popadiouk R.V., Dynamics of North American boreal mixedwoods, Environ. Rev. 10 (2002) 137-166.

[9] Dale M.R.T., Spatial Pattern Analysis in Plant Ecology, Cambridge University Press, Cambridge, 1999.

[10] Delaney J.R., Development of forest renewal standards for forest regeneration in Manitoba, Manitoba Forestry Branch, Winnipeg, 1995.

[11] Elliot-Fisk D.L., The boreal forest, in: Barbour M.G., Billings W.D. (Eds.), North American Terrestrial Vegetation, Cambridge University Press, NY, 1988, pp. 33-62.

[12] Farmer R.E. Jr., Seed ecophysiology of temperate and boreal zone forest trees, St. Lucie Press, Forida, 1997.

[13] Galipeau C., Kneeshaw D., Bergeron Y., White spruce and balsam fir colonization of a site in the southeastern boreal forest as observed 68 years after fire, Can. J. For. Res. 27 (1996) 139-147.

[14] Goldstein G.H., Brukaber L.B., Hinckley T.M., Water relations of white spruce (Picea glauca (Moench) Voss) at treeline in north central Alaska, Can. J. For. Res. 15 (1985) 1080-1087.

[15] Gray A.N., Spies T.A., Gap size, within-gap position and canopy structure effects on conifer seedling establishment, J. Ecol. 84 (1996) 635-645.
[16] Gray A.N., Spies T.A., Microsite controls on tree seedling establishment in conifer forest canopy gap, Ecology 78 (1997) 2458-2473.

[17] Greene D.F., Johnson E.A., Tree recruitment from burn edges, Can. J. For. Res. 30 (2000) 1264-1274.

[18] Greene D.F., Zasada J.C., Sirois L., Kneeshaw D., Morin H., Charron I., Simard M.J., A review of the regeneration dynamics of North American boreal forest tree species, Can. J. For. Res. 29 (1999) 824-839.

[19] Greene D.F., Kneeshaw D.D., Messier C., Lieffers V., Cormier D., Doucet R., Coates K.D., Groot A., Grover G., Calogeropoulos C., Modeling silvicultural alternatives for conifer regeneration in boreal mixedwood stands (aspen/white spruce/balsam fir), For. Chron. 78 (2002) 281-295.

[20] Harris W.C., Kazbems A., Kosowan A.L., Padburry G.A., Rowe J.S., Ecological regions of Saskatchewan, Canadian Forestry Service, Technical Bulletin No. 10, 1989.

[21] He F., Legendre P., Bellehumeur C., LaFrankie J.V., Diversity pattern and spatial scale: a study of a tropical rain forest of Malaysia, Environ. Ecol. Stat. 1 (1994) 265-286.

[22] Hush B., Miller C.I., Beers T.W., Forest Mensuration, Krieger Publishing Company, Florida, 1993.

[23] Jarvis J.M., Steneker G.A., Waldron R.M., Lees J.C., Reviews of silvicultural research: White spruce and trembling aspen cover types, mixedwood forest section, boreal forest region, Alberta, Saskatchewan and Manitoba, Canada, Forestry Research Branch, Publication No. 1156, 1966.

[24] Kazbems A., Kasowan A.L., Harris W.C., Mixed Wood Section in an Ecological Perspective, Saskatchewan Parks and Renewable Resources, Canadian Forestry Service Technical Bulletin No. 8, 1986.

[25] Kimmins J.P., Forest Ecology: A Foundation for Sustainable Management, Prentice Hall, New Jersey, 1997.

[26] Knapp A.K., Smith W.K., Factors influencing understory seedling establishment of Engelmann spruce (Picea engelmannii) and subalpine fir (Abies lasiocarpa) in southeast Wyoming, USA, Can. J. Bot. 60 (1982) 2753-2761.

[27] Lieffers V.J., Stadt K.J., Navratil S., Age structure and growth of understory white spruce under aspen, Can. J. For. Res. 26 (1996) 1002-1007.

[28] Oliver C.D., Development of northern red oak in mixed species stands in central New England, Yale University School of Forestry and Environmental Studies, Bulletin No. 91, 1978.

[29] Oliver C.D., Larson B.C., Forest Stand Dynamics, John Wiley and Sons, Inc., New York, 1996.

[30] Peterson C.J., Squiers E.R., An unexpected change in spatial pattern across 10 years in an aspen-white-pine forest, J. Ecol. 83 (1995) 847-855.

[31] Place I.C.M., The influence of seed-bed conditions on the regeneration of spruce and balsam fir, Canadian Department of Natural Resources, For. Bull. 177, 1955.

[32] Ripley B.D., Modeling spatial pattern, J. R. Stat. Soc. B 39 (1977) $172-212$.

[33] Rowe J.S., Factors influencing white spruce regeneration in Manitoba and Saskatchewan, Forestry Branch Division, Technical Note 3,1955 .

[34] Rowe J.S., Critiques of some vegetational concepts as applied to forests of northwestern Alberta, Can. J. Bot. 39 (1961) 1007-1017.

[35] Sulistiyowati H., Structure of the Mixedwood Boreal Forest along Chronosequences after Fire or Clearcutting in Southern Saskatchewan, M.Sc. thesis. University of Saskatchewan, Saskatoon, Saskatchewan, 1998.

[36] Thorpe J., Models of succession in the southern boreal forest, Saskatchewan Research Council, Publication No. E-2500-1-E-96, 1996.

[37] Thrasher-Haug J., Plant Species Diversity Pattern after Fire and Clearcutting disturbances in the Southern Boreal Forest of Saskatchewan, M.Sc. thesis. University of Saskatchewan, Saskatoon, Saskatchewan, 1997.

[38] Venables W.N., Ripley B.D., Modern Applied Statistics with S-Plus, Springer-Verlag, New York, 1994.

[39] Viereck L.A., Wildfire in taiga of Alaska, Q. Res. 3 (1973) 465-495.

[40] Young C.G., Dale M.R.T., Spatial pattern of vegetation in high arctic sedge meadows, Écoscience 6 (1999) 556-564. 